\title{
People or Preservation? How Electoral Accountability Reduces Human Cost in South Africa's National Parks
}

\section{AJ Golio}

https://doi.org/10.22151/politikon.41.2

AJ Golio, from Pittsburgh (United States), is a Master of Arts candidate in Political Science at Columbia University. He received his Bachelor's in International Political Economy and English from Fordham University in 2016 and spent two subsequent years in New Orleans working on issues of housing inequity and justice. His interests include matters of political inequality, protest and social movements, and the intersection of art, performance, and politics. Email:ajg2256@,columbia.edu.

\begin{abstract}
Natural protected areas (NPAs) are commonly used to preserve environmental biodiversity. Such policies, however, often harm rural communities. This article argues that the buman cost of NPAs is often because of a lack of formal electoral accountability that links national governments to these communities. Through the case of 1994 democratic elections in South Africa that signified the end of the apartheid, I show that an increase in electoral accountability can be associated with a decrease in the human cost of NPAs. Using scholarly observations and histories on NPAs in South Africa, and primary documents from governmental agencies, I examine the post-apartheid change in three areas pertinent to buman cost: Law and Intention, Communication and Community Involvement, and Land Restitution. In doing so, I demonstrate that the enfranchisement of black South Africans, who overwhelmingly populate the rural communities that are harmed by NPAs, has led to a shift in buman cost.
\end{abstract}

\section{Keywords}

Biodiversity; Electoral Accountability; National Parks; Preservation; Human Cost; South Africa 


\section{Introduction}

Land preservation has become an increasingly important international issue, as world leaders turn their attention toward the state of the environment. In this setting, natural protected areas (NPAs) like parks and preserves play an imperative role in protecting biodiversity, as well as easing the effects of desertification, sensitivity to drought (Stringer et al., 2009), and rapid urban expansion (Huang et al., 2018). However, the literature on NPAs is critical of how these parks also create substantial human cost in the developing world, and especially in Africa (Neumann, 1998), where many people rely on subsistence land use (Brechin et al., 1991; Chatty and Colchester, 2002). This conflict between the use of NPAs in Africa for positive environmental outcomes, and the harm they tend to inflict on local communities, suggests that further research is needed to find equilibrium between the two.

In this article, I look at the human cost of NPAs in depth and argue that a previously absent, yet crucial, component of the issue is electoral accountability. Existing research, while hinting at this relationship, has yet to explicitly connect accountability to the human cost of NPAs. Specifically, I will demonstrate that the substantial harm the land preservation policies in Africa exert upon rural communities is often due to the failures of formal electoral systems in holding governments accountable to these communities. I hypothesize that stronger electoral ties between governments and rural communities are associated with lower human cost NPAs. To substantiate this claim, the following pages will present a case study of South Africa, where an increase in electoral accountability was observed during the 1994 elections, the first in which black South Africans could fully participate. I identify three primary areas of concern for human cost-Law and Intention, Communication and Community Involvement, and Land Restitution—and compare the conditions in each of these areas in both pre- and post-apartheid South Africa. To do so, I mostly use secondary accounts and histories, supplemented by analyses of primary documents from the South African National Assembly and the government agency on South African National Parks. Overall, through this case study, I document the decline in the human cost of the nation's National Parks system post1994 and provide evidence for the claim that an increase in political accountability is associated with a decrease in human cost.

\section{The Human Cost of Protected Areas: A Literature Review}

Before delivering a history of national parks in Africa and their human cost, some key terms must be clarified. Firstly, I borrow the definition of a "protected area" from Brechin et al. (1991: 7), who understand it as "any finite area of land or water that comes under a systematic managerial regime." A natural protected area (NPA), then, has the explicit objective of land management for 
environmental and biodiversity protection. Research confirms that land preservation in NPAs is an essential part of maintaining the ecosystems, wildlife, and natural habitats threatened by climate change and human impact (Stringer et al., 2009; Huang et al., 2018). For instance, evidence shows that NPAs are effective in meeting global biodiversity targets (Chape et al., 2005), and there is a decline in the loss of natural land-cover at protected sites in Africa (Beresford et al., 2013). As such, NPAs are an integral and indispensable part of environmental protection. As a salient issue across the world, including in Africa (Lubbe, 2017), NPAs exist in some form in nearly every country (Brechin et al., 1991).

Governments play a key role in land preservation and the management of NPAs. In most countries, NPAs are designated and maintained by the central government, exemplified by National Parks (Chatty and Colchester, 2002; Brechin et al., 1991). The tendency toward governmental management becomes clear when viewed through the lens of space. The designation of an NPA necessitates a portion of land, and states, by definition, represent some kind of institutionalized authority and control over this land (North, 1981; Tilly, 1985). In a system of state-controlled preservation, NPAs are a result of intentional domestic policy choices that are shaped by competing interests (Duffy, 2000).

Most policy on NPAs and land preservation across the world follows the example of the United States. The U.S. introduced the world's first National Park in 1872, Yellowstone, based on the assumption that conservation of land requires extreme restriction of human use of that land (Chatty and Colchester, 2002). This "fortress design" style quickly became the prominent preservation practice across the world (Thondhlana and Cundill, 2017), so much so that "the ideas that people should not live in protected areas or consume their resources are virtually synonymous with the national park ideal" (Brechin et al., 1991: 10). NPAs, then, can be understood as excluding human use entirely (Brechin et al., 1991; Chatty and Colchester, 2002). The "fortress design" and the policies required for such a mandate are, however, not always well suited for other countries, as in the United States relatively few people rely on subsistence land use (Brechin et al., 1991). Across sub-Saharan Africa, many individuals live in rural communities that require the use of local natural resources for survival (Anthony, 2007). Therefore, the implementation of "fortress design" NPAs can lead to significant human cost.

As a second key term, I use "human cost" to denote the negative impacts on a community, that interfere with its societal and economic development. The relationship between NPA policies in Africa and the human cost for those who live in and around them is the primary concern of this article. Historically, this relationship has been a sour one, to put it lightly. NPAs often run in tandem with the forced removal of communities that live in or use the designated area. This practice, while 
seemingly extreme, has been quite common across sub-Saharan Africa (Anthony, 2007). In Tanzania, a country that boasts the largest protected land area in Africa, over half of the preservation endeavors involved evictions (Brockington, Sachedina, and Scholfield, 2008: 567). An estimated 1,200 persons were displaced from the country's well-known Serengeti National Park alone (Neumann, 1998). Furthermore, in Uganda, in 1983, the creation of Lake Mburo National Park involved the displacement of an estimated 4,500 families (Pearson and Muchunguzi, 2011: 126). The inability to cultivate the land for subsistence or the use of natural resources, one of the core tenants of "fortress design", leaves many communities economically deprived. In Tanzania, the Maasai that live within the confines of the Ngorongoro Conservation Area are worse off than similar Maasai groups who do not (Galvin et al., 2002). The exclusion of local communities applies not only to economics, but also the policy-making processes that form NPAs, as "[t]he exclusion of local people as knowledgeable active participants in management" (Goldman, 2001: 65) is widespread. ${ }^{1}$

Accounts of human cost suggest that balancing the environmental and social outcomes is essential to the goals of preservation, as hostility resulting from local resentment of NPAs presents a significant detriment to the proper maintenance of ecosystems (Fabricius and de Wet, 2002; Brockington, Sachedina, and Scholfield, 2008). It is therefore imperative to bridge the gap between these natural and social concerns. Here, my article contributes to the conversation by bringing electoral accountability into the picture.

\section{Preservation and Electoral Accountability: A Theoretical Framework}

While mechanisms of formal accountability among governments and those they govern is a dense and complex topic, its basic logic can be explained through the self-interested politician. In a competitive election, where this policy-maker faces a punishment of being voted out of the office or a reward of being voted in, she must advocate for the desires of her constituents in order to gain power (Ashworth, 2012). Thus, the representative remains accountable to protect the interests of the represented. Without free and fair elections, this system of formal accountability either does not exist, or is dysfunctional to some degree, and politicians may have little incentive to address the problems of the underprivileged. The staggering human cost of land preservation across Africa suggests a breakdown of this political accountability mechanism.

However, matters of environmental concern, like biodiversity protection and land preservation, can lead to cases where an incumbent is incentivized to act against the voters' short-

\footnotetext{
${ }^{1}$ For those that live adjacent to NPAs, complaints about the negative impacts of the wildlife itself are numerous. In fact, encounters with wildlife are the primary source of dissatisfaction, according to local-level public opinion data (Anthony, 2007; Pearson and Muchunguzi, 2011). Wild animals, which often call the parks home, destroy crops in the surrounding communities, graze on pasture intended for livestock, and carry diseases (Pearson and Muchunguzi, 2011).
} 
term interests for the sake of their long-term interests (Bueno de Mesquita, 2007; Daley and Snowberg, 2011). Therefore, a decision in favor of a policy that will fight climate change, a longterm interest, at the expense of short-term economic growth is possible despite a potential shortterm electoral punishment (Ashworth, 2012: 184). For example, disaster preparedness spending, a policy that is not likely to have short-term electoral reward, is nonetheless a sensible policy as it has potential life-saving benefits in the long run (Healy and Malhotra, 2009).

It is possible to relate such cases to NPAs and human cost. Accountability mechanisms could be functional in a sense that African politicians do represent the interests of their constituents, but they incur short-term human cost, to trade off in favour of the long-term benefits of biodiversity conservation. Yet, this outcome is unlikely because as existing research shows, high human cost and the resulting poverty, marginalization, and hostility subverts conservation goals (Fabricius and de Wet, 2002; Brockington, Sachedina, and Scholfield, 2008). Therefore, the trade-off here would result in neither short-term social benefit nor long-term environmental protection.

Instead, historical land preservation policy can be better explained through a common dynamic wherein systems of governmental accountability tend to respond to economic elites, not the laypeople that typically make up the rural and subsistence communities that are negatively affected by NPAs (Gilens, 2012; Diop, 2012; Mizuno, 2016). This issue becomes apparent by examining public opinion toward preservation, such as Infield's (1988) study, in which positive attitudes toward NPAs increase in correlation with an increase in affluence and education levels. This is likely because most of the benefits of NPAs are disproportionately received by urban areas and economic elites. For instance, historically, parks in Africa tended to be only accessible to highranking chiefs or colonial figures, and excluded laypeople and most indigenous Africans (Brechin et al., 1991). While NPAs have recently become nominally more accessible for all, their economic benefits are still far out of the reach of rural communities. Profits from park tourism in Kenya tend to be centralized in urban centers like Nairobi, instead of going to local businesses (Brechin et al., 1991). Urban companies gain large revenues from preservation and eco-tourism, but incur little, if any, of the cost that comes with them (Obunde, 2005; Pearson and Muchunguzi, 2011).

In an era of heightened global environmental and biodiversity concerns, as reflected in the signing of the Paris Climate Accord and dire reports from the United Nations Intergovernmental Panel on Climate Change (Davenport 2015; Davenport 2018), countries that take action toward biodiversity conservation can receive rewards in the form of improved international relations (Duffy, 2000). As Duffy (2000) points out, African wildlife holds a prominent position in the Western imagination, and African biodiversity protection is a highly salient issue among the Western public. In the United Kingdom, for example, Prince Harry holds a secondary role as the President of the 
conservation NGO African Parks Network (Mfula 2018). With African biodiversity holding such a prominent position among the Western populace, national governments in Africa could pursue NPAs to please these groups, obtain their tourism dollars, and secure a diplomatic victory, unconcerned with the human cost laid on rural constituents.

Lastly, legacies of human cost could be explained by the fact that countries in Africa have historically not been very democratic. Most African nations spent much of the twentieth century as colonies of European powers, and upon independence, fell into various authoritarian and one-party regimes. In 2017, the Economist Intelligence Unit's Democracy Index rated twenty-four countries in sub-Saharan Africa as authoritarian regimes. The Freedom in the World report for the year 2018 notes little progress in democratization across sub-Saharan Africa, with only $11 \%$ of people living in countries that are considered "free". Without strong democratic elections, there is little reason to think that formal accountability between governments and people can exist at all. In this scenario, human cost is of little consequence simply because the victims have no means of electoral punishment.

In this section I presented three explanations of accountability failure which prompt governments across sub-Saharan Africa to pursue high-human cost NPAs. (1) They could be accountable to rural communities by responding to long-term environmental interests at the expense of their short-term social concerns, but this is not likely. (2) They could choose to be accountable only to economic elites instead of the rural communities, relying instead on patronage networks to get elected (van de Walle 2003; Corstange 2016). (3) They could simply not be held accountable at all, in the case of non-democratic regimes. All of these possibilities suggest that there is a high risk of human cost, incurred by those living in areas of at-risk biodiversity, or simply rural places that make attractive locations for potential NPAs. I hypothesize that this risk can be reduced through an improvement in electoral accountability, especially in rural communities.

\section{A Case Study of South Africa}

In order to test my hypothesis, I now turn to a case study. South Africa is ideal for examining how NPA systems change over time, and how responsive they are to these institutional changes, given its extensive history with NPAs. In 1898, the establishment of the Sabie Game Reserve in the Transvaal Republic marked the second of such preservation efforts in the world, after the establishment of Yellowstone in the United States over one decade earlier (Cock and Fig, 2002). This effort shows that early twentieth-century South Africa championed the United States' "fortress design" application of NPAs (Carruthers, 2008; Dlamini, 2012). The Sabie Game Reserve later survived the unification and independence experiences and was renamed as Kruger National Park, which to this day remains South Africa's largest park and the nation's flagship preservation effort. 
Since the original National Parks Act of 1926, management of all the National Parks in South Africa, which today number twenty, has been institutionalised under the Department of Environmental Affairs and Tourism, and the governmental organization South African National Parks (SANParks) (SANParks, n.d.a, SANParks, n.d.b). In this sense, NPA management in South Africa as an institutionalised and legislated governmental endeavour is subject to frameworks of formal electoral accountability.

This robust history of NPAs in South Africa also includes accounts of violence and disregard toward rural communities, which indicates that pre-1994 South Africa represents high human cost occurrences. In writing about SANParks, Moore and van Damme (2002: 64) are blunt, stating, "Biodiversity preservation was the exclusive concern of conservationists in [SANParks], whilst human and social issues were mostly ignored." Household interview data from a rural community in Natal, South Africa, reveals markedly negative opinion toward the local NPA, despite positivity toward the concept of environmental conservation generally (Infield 1988). It also appears that perceptions of NPAs in South Africa varied significantly among certain groups. As mentioned earlier, a positive opinion was correlated with affluence and education level (Infield, 1988). A study of South African reserves also reveals that those affiliated with SANParks, like reserve managers, perceive little conflict with local communities, where the communities themselves hold grievances over restricted access and lack of benefits (Thondhlana and Cundill, 2017). It is not difficult to imagine South Africa's history of forced removals from NPAs and other negatively impactful land preservation practices to be linked to un-democratic tendencies. Rural peoples typically lack the ability to hold South African politicians accountable for human cost issues, as confirmed by the authors here:

People [who were] forcibly relocated to make way for conservation in South Africa shared a number of characteristics... They lived in underdeveloped parts of the country with weak formal infrastructure. These small communities therefore lacked political leverage (Fabricius and de Wet, 2002: 143).

Several scholars categorize the practices of SANParks firmly into the racially divided apartheid regime that ruled South Africa under the National Party from 1948-1994, because by and large, the forcibly removed rural communities were mostly composed of black South Africans (Cock and Fig, 2002; Carruthers, 2008; Dikeni, 2016).

A shift in conservation philosophy toward a more militant "management by intervention" (Carruthers, 2008: 203) style in post-World War II South Africa, coincided with the 1948 ascendance of the National Party, and the beginning of the apartheid. This is not necessarily surprising, given the lack of representation of black South Africans pre-1994, when they were excluded from, among other sectors of government, serving on the board of SANParks (Cock and Fig, 2002). But the rural 
communities that faced the human cost of preservation were largely made up of black South Africans, and therefore, an increase in electoral accountability towards black South Africans would yield an opportunity to push for accountability to these communities. In 1994, the National Party's control of the South African government was challenged when black citizens became enfranchised, marking what many consider the first fully democratic elections in the country (Carruthers, 2008; Ross, 2008; Thompson, 2014). The 1994 election signalled a sweeping shift in electoral accountability in favour of black South Africans, and therefore, for rural communities and the victims of past SANParks policy. As historical accounts confirm, despite some imperfections, the election was overall representative of these communities (Ross, 2008; Thompson, 2014), with an estimated 90\% voter turnout in April 1994 (Beinart, 2001: 291). Therefore, this case study includes an increase in electoral accountability at a particular point in time (the 1994 elections) that makes during-apartheid and post-apartheid comparison possible.

There is some debate, however, over how "accountable" South Africa's government became after these elections. The African National Congress (ANC), which became the ruling party, has controlled the national government ever since (Thompson, 2014). Thus, there is concern over electoral accountability under the dominant party rule, and despite the practice of largely free and fair elections with multiple parties, scholars express scepticism over responsiveness to voters within ANC supremacy (Graham, 2014). Others find, however, that at the local level ANC politicians are largely responsive to voter opinion, and re-nomination is closely correlated with local government performance (Wegner, 2018). Another debate concerns the system of proportional representation adopted by South Africa, and whether politicians in states that utilize proportional representation face any incentive to respond to their constituents in rural and agrarian areas instead of national party platforms (Barkan, 1995). Other scholars assert that such proportional representation is best for highly fractionalized democracies, and note the amendments of the South African government to combat parliament's detachment from voters (Reynolds, 1995). South Africa also ranks consistently high on international measures of democratization (Freedom House, 2018; Economist Intelligence Unit, 2018), suggesting that concerns over governmental legitimacy in South Africa are largely unfounded.

Therefore, South Africa as a case study adequately mimics the hypothesis of human cost and accountability established earlier, which suggests that a decrease in human cost, especially when it comes to SANParks practices, should be observed after the 1994 shift toward electoral accountability for black and rural citizens. The following section provides an analysis of the evidence of this decrease in human cost. These results are divided into three main areas of South African NPA policy and practice that impacts on human cost. Each of these is examined in both during- and post- 
apartheid periods, for that the differences can also be attributed to the increase in electoral accountability.

Firstly, in the Law and Intention section, I analyse and compare primary documents from SANParks and laws from the South African National Assembly pertinent to land preservation. This constitutes a study of formal governmental change. Secondly, as important as changes within policy, are changes within practice. Works on NPAs' human cost note high instances of local communities being left out of the decision-making process and economic development (Goldman, 2001; Galvin et al., 2002). There is evidence in existing literature to determine that communication with populations affected by NPAs leads to desirable social outcomes (Bidol and Crowfoot, 1991), most expressively the general public approval of NPAs, as occurred in South Africa's neighbouring Swaziland (Ntshalintshali and McGurk, 1991). Therefore, evidence of an increase in Communication and Community Involvement would indicate fewer human cost outcomes. I document this change through secondary accounts and histories, as well as data on SANParks employment. Finally, Land Restitution consists of policies that involve returning land to its original inhabitants of previously displaced communities. The literature on NPAs stress forced removals as a primary grievance of local communities (Neumann, 1998; Pearson and Muchunguzi, 2011), and although a history as traumatic as this one may not ever be fully rectified, several authors point to these policies as one significant and necessary area of redress (Cock and Fig, 2002; Moore and van Damme, 2002). Any change in human cost should include a change on this front, as I demonstrate, again, via analysis of secondary documents in the following section.

\section{Results}

\section{Law and Intention}

A post-1994 decrease in the human cost of NPAs in South Africa can be observed, first through laws and policies that governed the NPAs. "A new beginning was to be made in SANParks, which would see the introduction of a more inclusive form of conservation aligned with South Africa's new democracy," (Moore and van Damme, 2002: 66). This new beginning is evident, first, in the new philosophies that governed SANParks. For instance, in 1995, the organization introduced its Social Ecology program (Moore and van Damme, 2002), with the explicit purpose to build more positive relationships with communities living in the vicinity of National Parks, according to the SANParks website as of January 28, 2019.

An investigation of other primary documents from SANParks reveals similar peopleoriented intentions. In 2012, for example, the organization released a report on recent social investment programs, titled, "From Fortress Conservation to People and Conservation" (Magome and Daphne, 2012). In it, SANParks CEO Dr. David Mabunda acknowledges a "painful 
conservation past where public institutions were used to implement a well-crafted system of alienating certain spheres of society," while advocating an imperative to "re-orient protected areas" toward the inclusion of social considerations as well as conservation goals (Magome and Daphne, 2012: iii). Even SANParks publications that are not specifically dedicated to the topic of human cost extoll a similar attitude. The organization's publicly available 2018 Annual Report states,

Historically, the national parks excluded the majority of South Africa's people (...) To ensure an inclusive national parks system, SANParks formulated a comprehensive Socio-Economic Development strategy to assist with the development of communities neighbouring the parks (South Africa National Parks 2018, 8).

These statements present a stark contrast to the pre-1994 tendency, outlined above, wherein the human cost of preservation was summarily ignored, if not outright exacerbated.

Brief analyses of the laws that give SANParks its mandate also reveal the shift toward a more community-centred organisation. In 2003, the National Environmental Management: Protected Areas Act effectively replaced the 1976 National Parks Act, through the efforts of the South African legislature. Both laws provided the legal groundwork for the establishment of natural protected areas for the purpose of ecology and biodiversity protection. The 1976 law, however, makes zero mention of community development, participation, local or social needs, or even simply "humans" or "people" (1976). These omissions fit the, previously outlined, "fortress design" preservation mentality. The 2003 replacement, on the other hand, directs as one of its objectives: "To promote participation of local communities in the management of protected areas" (page 12). It makes explicit mention of social and economic development (on pages 20,32,34), and provides entire sections on park co-management (page 34) and public participation (page 26). The disparity between these two legislative acts and the emphasis each places on human cost indicates a sweeping change in preservation policy, and the two laws passed on either side of the 1994 election.

\section{Communication and Community Involvement}

Given how imperative the systems of communication and community involvement are to implementing NPAs in a socially responsible way, the SANParks shift that occurred after the widening of electoral accountability in 1994 should include noticeable effects on the practice of intentional inclusion of people living in the vicinity of National Parks. Indeed, there is evidence of such an increase in several scholarly accounts. For instance, a process of, "formalization of interactions between [National Parks] and neighboring communities" (Cock and Fig, 2002: 142-143) that involved public consultations and forums with conservation bodies on social issues such as water access, wildlife impact, and economic opportunities is observed. The presence of community and neighbour advisory structures on the planning and management of parks have become 
commonplace (Moore and van Damme, 2002). Overall, interactions between representatives of SANParks and members of neighbouring communities are much more prevalent after the election of 1994.

The literature on NPA management also stresses practices like the Social Impact Assessment as vital for the inclusion of local communities in the political processes. This allows for social concerns to be integrated into park planning and policy, through several tools of predicting potential adverse effects (Hough, 1991). These tools, virtually non-existent in South Africa pre-1994, have been used by SANParks since the end of apartheid rule (Moore and van Damme, 2002). Similarly, schemes of tourism revenue sharing with local communities have been observed (Moore and van Damme, 2002; Cock and Fig, 2002). Revenue sharing programs tend to improve local public opinion and attitudes toward NPAs (Groom and Harris, 2008). Significant steps toward community revenue sharing programs came in 1997 and 1998, when the SANParks Board "instituted organizational restructuring" (Cock and Fig, 2002: 145), and targeted local economic opportunity as a strategic concern. The formalization of these practices is exemplified in endeavors like the Kruger Social Ecology Unit and the Skukuza Alliance, both of which provide "business opportunities for local artists and traders" (Moore and van Damme, 2002: 68).

Finally, there is evidence that SANParks became more inclusive, not just at the community relations level, but also within the organization itself. Table 1 below shows the proportion of individuals of different races employed by SANParks in 1999 and 2018. The raw numbers for employment in 1999, shown in the table, were reported by Cock and Fig (2002: 141) and by the SANParks Annual Report (2018: 167-168) for the more recent figures. In both cases, the figures were meant to demonstrate gender equity in SANParks employment, so they were categorised by gender as well as by race and skill level. For this article, both genders have been combined and the raw numbers have been put in proportions of each employment skill level. 
Table 1: SANParks Employment Proportions by Race and Skill Level, 1999 vs. 2018

\begin{tabular}{ccccccccc}
\hline & \multicolumn{4}{c}{1999} & \multicolumn{5}{c}{2018} \\
\hline & African & White & Other* & Total & African & White & Other* & Total \\
Management & .178 & .753 & .069 & 1.0 & .428 & .405 & .167 & 1.0 \\
Skilled & .224 & .676 & .100 & 1.0 & .677 & .139 & .184 & 1.0 \\
Semi-Skilled & .666 & .090 & .244 & 1.0 & .768 & .018 & .214 & 1.0 \\
Unskilled & .923 & .003 & .074 & 1.0 & .910 & .001 & .089 & 1.0 \\
Total & .749 & .126 & .125 & 1.0 & .772 & .063 & .165 & 1.0 \\
\hline
\end{tabular}

Sources: Cock and Fig 2002: 141; SANParks Annual Report 2018: 167-168

* Includes racial categories "Coloured" and "Asian" from Cock and Fig (2002); "Coloured" and "Indian” from SANParks (2018).

As can be observed, the proportion of Africans employed at the highest skill levels of SANParks, including many of the top management positions, rose significantly from 1999 to 2018. This change further indicates the inclusion of black South Africans in land preservation efforts post1994. Though this shift in employment was not immediate, there is reason to think the effect of the 1994 election would be slow to progress on this front: South Africa's democratic transition was a negotiation that left many bureaucrats in place for several years, including in SANParks (Cock and Fig, 2002: 134). Therefore, the employment composition changes observed after 1999 can still be attributed to practices adopted after the 1994 election, despite delays in the actual makeup of the workforce. Overall, increased interaction between SANParks and local communities, as well as the prevalence of formal practices like the Social Impact Assessment, revenue sharing schemes, and the observable increase in the employment of black South Africans in leadership positions, contribute to the narrative of a post-1994 decrease in human cost.

\section{Land Restitution}

As mentioned, displacement due to land preservation policy was common in South Africa before the 1994 election, and represented one of the most harmful human costs of SANParks practice. Secondary sources observe the regular practice of evictions and forceful removals of black and indigenous South Africans from land designated as an NPA (Cock and Fig, 2002; Moore and van Damme, 2002). For example, in his fieldwork notes from the year 1994, Dikeni (2016: 26) quotes from a conversation with a resident of the village of Cork, next to the Kruger National Park, in which she recalls the policy that pushed her out of the NPA: "We were controlled like animals and placed on land that we cannot use. Our families were often separated without their will.” The flagship 
Kruger National Park was notable among instances of relocation (Dlamini, 2012), with an estimated removal of over 3,000 people by the South African government in the name of biodiversity conservation (Dikeni, 2016: 22). The Makuleke community, for example, was forcibly evicted from their territory in 1969 to make way for a new section of Kruger and placed on land much less suited for farming and grazing (Fabricius and de Wet, 2002).

Land restitution was observed as a new standard practice after 1994, with several prominent claims successfully resolved through SANParks and the South African Ministry of Land Affairs. The Makuleke, for instance, were allowed ownership of their land again in 1998 (Cock and Fig, 2002; Moore and van Damme, 2002). The process was not severely limited, either. Fabricius and de Wet (2002: 143) note examples of land claims in eleven different NPAs across nearly every province of South Africa, from Blyde Canyon in Mpumalanga Province to Kalahari Gemsbok National Park in Northern Cape Province, just in the eight years between 1994 and 2002. Consequently, the prevalence of land restitution in NPAs across South Africa is directly linked to the first fully democratic elections, because it was only under the provisions of the new Constitution that these claims could be legally recognized (Moore and van Damme, 2002).

The social benefits of land restitution policies are numerous, providing communities like the Makuleke and Khomani San in southern Kalahari with not only commercial and residential rights, but also aspects of cultural identity tied to the land that had been taken (Cock and Fig, 2002). It is also notable, however, that this decrease in human cost does not have to come with negative conservation impacts like biodiversity loss, as suggested by the original philosophy of "fortress design" preservation. On the contrary, the conservation benefits seem to be numerous; from a decrease in poaching attributable to improved community relations, to the development of new institutions and conservation models like the SANParks/community joint management structures that are now prevalent in South African NPAs (Fabricius and de Wet, 2002). Thus, the evidence of human cost change from the listed three areas had observable substantive impacts. For instance, local public opinion on Kruger National Park has improved over time (Anthony 2007). In fact, Anthony's (2007: 240) Table 1, based on a survey of community respondents in 2004, indicates that large majorities replied affirmatively to "liking" Kruger, and responded that they are "satisfied" that their village is located near the Park. These statistics present a vastly different picture of positive public opinion than the history of National Parks in South Africa before the 1994 election.

\section{Alternative Explanations}

Two alternative explanations could be used to explain the decrease in human cost of South Africa's NPAs around 1994, but neither holds up against existing evidence and reasoning. It could be argued that this decrease is due to either (1) changing international norms of socially responsible 
preservation, or (2) the influence of NGOs. The government under National Party rule, however, was notoriously stubborn in its resistance to international norms and behavioural demands, so it is difficult to imagine that these alone would have altered the scenario in South Africa. For instance, starting in 1977 with the United Nations embargo on arms sales to South Africa, the apartheid government faced intense international scrutiny to end its racially discriminatory practices, but did not relent for many years (Thompson 2014, 222). Further, it was only after the ANC came to power, claims Dikeni (2016: 31), that the environmental NGOs were invited to work with SANParks and other conservation agencies. Finally, if low-human cost preservation is influenced primarily by these factors, then similar changes should also be observed in other sub-Saharan African nations, even without a change in accountability. Yet, there is little backing for such shift elsewhere, given that recently published literature sheds light on ongoing human rights abuses in NPAs in many other countries (Brockington, Sachedina, and Scholfield, 2008; Goldman, 2011; Pearson and Muchunguzi, 2011). For example, neighbouring Botswana, which shares the bi-national "transfrontier” Gemsbok National Park with South Africa, has had a regime of one-party rule since its independence, and therefore no electoral accountability shift. There, forced removals and "continued disrespect" of local San communities continued long after South Africa ended the practices (Cock and Fig, 2002, 139). There is little evidence to back these alternative explanations, and therefore, the electoral accountability-based arguments I advance in this article offer a more satisfactory answer.

\section{Conclusion}

Land preservation policies must strike a delicate balance between important biodiversity conservation goals and the needs of the rural communities living on and/or around these lands, which are often subsistent and lacking political leverage. Building on histories of human cost and theories of electoral accountability, I contend that an increase in electoral accountability leads to a decrease in human cost. The case study of South Africa has confirmed this thesis, with the democratic election of 1994 proving to be a pivotal turning point for both electoral accountability, and National Park policy and procedure when it comes to Law and Intention, Communication and Community Involvement, and Land Restitution. Surely, there is still room for improvement on both fronts in modern South Africa, but steps forward have been taken in tandem.

The findings of this article touch upon the political science literature on conservation policy and electoral accountability, suggesting that fair elections, meaningful participation in park management, and access to information on NPAs, should lead to more socially responsible practices and therefore better conservation outcomes. However, further research on this topic is needed. The use of natural experiments and the ability to survey human cost and public opinion on NPAs in a local community both before and after an accountability shift should present convincing evidence. 
For instance, in South Africa, NPA opinion data from before 1994, as represented in Infield (1988), can be replicated.

In terms of policy, governments that wish to provide solutions to both environmental and human rights issues may take steps toward greater enfranchisement and local participation in NPA procedure. In this article I have shed some light on the relationship between conservation outcomes, social responsibility, and electoral accountability, and suggested that the strength of each is dependent on the others. Preservation of biodiversity resources is a goal that the world must achieve, and it must be accomplished with the humanity of every individual in mind.

\section{References}

Anthony, Brandon (2007): 'The Dual Nature of Parks: Attitudes of Neighbouring Communities towards Kruger National Park, South Africa', Environmental Conservation 34(3): pp. 236-245. DOI: https://doi.org/10.1017/S0376892907004018

Ashworth, Scott (2012): 'Electoral Accountability: Recent Theoretical and Empirical Work', Annual Review of Political Science 15: pp. 183-201. DOI: https://doi.org/10.1146/annurev-polisci-031710$\underline{103823}$

Barkan, Joel D. (1995): 'Elections in Agrarian Societies', Journal of Democracy 6(4): pp. 106-114. DOI: https://doi.org/10.1353/jod.1995.0058

Beinart, William (2001): Twentieth-Century South Africa. Oxford: Oxford University Press.

Beresford, Alison E. et al. (2013): 'Protection Reduces Loss of Natural Land-Cover at Sites of Conservation Importance across Africa', PLoS One 8(5): pp. 1-7. DOI: https://doi.org/10.1371.journal.pone.0065370

Bidol, Patricia and James E. Crowfoot (1991): 'Toward an Interactive Process for Siting National Parks in Developing Nations', in Patrick C. West and Steven R. Brechin (eds.) Resident Peoples and National Parks. Tucson: The University of Arizona Press. pp. 283-300.

Brechin, Steven R. et al. (1991): 'Resident Peoples and Protected Areas: A Framework for Inquiry,' in Patrick C. West and Steven R. Brechin (eds.) Resident Peoples and National Parks. Tucson: The University of Arizona Press. pp. 5-30.

Brockington, Dan, Hassan Sachedina, and Katherine Scholfield (2008): 'Preserving the New Tanzania: Conservation and Land Use Change', The International Journal of African Historical Studies 41(3): pp. 557-579. Available at: https://www.jstor.org/stable/40282531 (7 December 2018).

Bueno de Mesquita, Ethan (2007): 'Politics and the Suboptimal Provision of Counterterror', International Organization 61(1): pp. 9-36. DOI: https://doi.org/10.1017/S0020818307070087 
Carruthers, Jane (2008): 'Conservation and Wildlife Management in South African National Parks 1930s-1960s', Journal of the History of Biology 41(2): pp. 203-236. DOI: https://doi.org/10.1007/s10739-007-9147-3

Chape, S. et al. (2005): 'Measuring the Extent and Effectiveness of Protected Areas as an Indicator for Meeting Global Biodiversity Targets', Philosophical Transactions of the Royal Society: Biological Sciences 360(1454): pp. 443-455. DOI: https://doi.org/10.1098/rstb.2004.1592

Chatty, Dawn and Marcus Colchester (eds.) (2002): Conservation and Mobile Indigenous Peoples: Displacement, Forced Settlement and Sustainable Development. New York: Berghahn Books.

Cock, Jacklyn and David Fig (2002): 'From Colonial to Community-Based Conservation: Environmental Justice and the Transformation of National Parks (1994-1998)', in David A. McDonald (ed.) Environmental Justice in South Africa. Athens: Ohio University Press. pp. 131-155.

Corstange, Daniel (2016): The Price of a Vote in the Middle East: Clientelism and Communal Politics in Lebanon and Yemen. Cambridge: Cambridge University Press. DOI: https://doi.org/10.1017/CBO9781316227169

Daley, Brendan and Erik Snowberg (2011): 'Even if it is not Bribery: The Case for Campaign Finance Reform', Journal of Law, Economics, and Organization 27(2): pp. 324-349. DOI: https://doi.org/10.1093/ileo/ewp012

Davenport, Coral (2015): 'Nations Approve Landmark Climate Accord in Paris', New York Times, (12 December 2015). Available at: https://www.nytimes.com/2015/12/13/world/europe/climatechange-accord-paris.html (7 December 2018).

Davenport, Coral (2018): 'Major Climate Report Describes a Strong Risk of Crisis as Early as 2040', New York Times, (7 October 2018). Available at: https://www.nytimes.com/2018/10/07/climate/ipcc-climate-report-2040.html $\quad 7$ December 2018).

Dikeni, Leslie (2016): Habitat and Struggle: The Case of the Kruger National Park in South Africa. Johannesburg: Real African Publishers.

Diop, Samba (2012): 'African Elites and their Post-Colonial Legacy: Cultural, Political and Economic Discontent - by Way of Literature', Africa Development 37(4): pp. 221-235. Available at: https://www.jstor.org/stable/afrdevafrdev.37.4.221 (7 December 2018).

Dlamini, Jacob Simon Tilo (2012): Putting the Kruger National Park in its Place: A Social History of Africans, Mobility and Conservation in a Modernizing South Africa, 1900-2010. Yale University: ProQuest Dissertations Publishing.

Duffy, Rosaleen (2000): Killing for Conservation: Wildlife Policy in Tanzania. Bloomington: Indiana University Press. 
Fabricius, Christo and Chris de Wet (2002): 'The Influence of Forced Removals and Land Restitution on Conservation in South Africa', in Dawn Chatty and Marcus Colchester (eds.) Conservation and Mobile Indigenous Peoples: Displacement, Forced Settlement and Sustainable Development. New York: Berghahn Books. pp. 142-157.

Freedom House (2018): 'Freedom in the World 2018: Democracy in Crisis.' Available at: https://freedomhouse.org/sites/default/files/FH FITW Report 2018 Final SinglePage.pdf (7 December 2018).

Galvin, Kathleen A. et al. (2002): 'Compatibility of Pastoralism and Conservation? A Test Case Using Integrated Assessment in the Ngorongoro Conservation Area, Tanzania', in Dawn Chatty and Marcus Colchester (eds.) Conservation and Mobile Indigenous Peoples: Displacement, Forced Settlement and Sustainable Development. New York: Berghahn Books. pp. 36-60.

Gilens, Martin (2012): Affluence and Influence: Economic Inequality and Political Power in America. Princeton, NJ: Princeton University Press. DOI: https://doi.org/10.2307/i.ctt7s1jn

Goldman, Mara J. (2011): 'Strangers in Their Own Land: Maasai and Wildlife Conservation in Northern Tanzania', Conservation and Society 9(1): pp. 65-79. DOI: https://doi.org/10.4103/0972$\underline{4923.79194}$

Graham, Victoria (2014): 'The Quality of South Africa's Electoral Accountability 1994-2014: Freedom, Flaws and Food Parcels', Journal of Comparative Politics 7(2): pp. 52-72.

Groom, Rosemary and Stephen Harris (2008): 'Conservation on Community Lands: the Importance of Equitable Revenue Sharing', Environmental Conservation 35(3): pp. 242-251. DOI: https://doi.org/10.1017/S037689290800489X

Healy, Andrew and Neil Malhotra (2009): 'Myopic Voters and Natural Disaster Policy', American Political Science Review 103(3): pp. 387-406. DOI: https://doi.org/10.1017/S0003055409990104

Hough, John (1991): 'Social Impact Assessment: Its Role in Protected Area Planning and Management', in Patrick C. West and Steven R. Brechin (eds.) Resident Peoples and National Parks. Tucson: The University of Arizona Press. pp. 274-283.

Huang, Chun-Wei et al. (2018): 'The Importance of Land Governance for Biodiversity Conservation in an Era of Global Urban Expansion', Landscape and Urban Planning 173: pp. 44-50. DOI: https://doi.org/10.1016/j.landurbplan.2018.01.011

Infield, Mark (1988): 'Attitudes of a Rural Community towards Conservation and a Local Conservation Area in Natal, South Africa', Biological Conservation 45: pp. 21-46. DOI: https://doi.org/10.1016/0006-3207(88)90050-X

Lubbe, Willem Daniel (2017): ‘Africa's Ambitious New Biodiversity Laws Come with Teeth, Will Protect People too', The Conversation, $(10$ September 2017). Available at: 
http://theconversation.com/africas-ambitious-new-biodiversity-laws-come-with-teeth-willprotect-people-too-83109 (7 December 2018).

Magome, Hector and Paul Daphne (2012): “From Fortress Conservation to People and Conservation" - SANParks and a Developmental Approach to Conservation in the 21st Century.' SANParks, July 2012. Available at: https://www.sanparks.org/assets/docs/about/reports/socialinvestment-report-2012.pdf (7 December 2018).

Mfula, Chris and Joe Brock (2018): 'On Solo Zambia Trip, Prince Harry Offers Help to Boost Elephant Numbers', Reuters, (26 November 2018). Available at: https://www.reuters.com/article/us-zambia-britain/on-solo-zambia-trip-prince-harry-offers-helpto-boost-elephant-numbers-idUSKCN1NV2E0 (7 December 2018).

Mizuno, Nobuhiro (2016): 'Political Structure as a Legacy of Indirect Colonial Rule: Bargaining between National Governments and Rural Elites in Africa', Journal of Comparative Economics 44(4): pp. 1023-1039. DOI: https://doi.org/10.1016/i.jce.2016.03.002

Moore, Kevin and Lynette Masuku van Damme (2002): 'The Evolution of People-and-Parks Relationships in South Africa's National Conservation Organization', in Eureta Janse van Rensburg (ed.) Environmental Education, Ethics and Action in Southern Africa. Pretoria: Human Sciences Research Council. pp. 61-73.

North, Douglass C. (1981): Structure and Change in Economic History. New York: W.W. Norton \& Co.

Ntshalintshali, Concelia and Carmelita McGurk (1991): 'Resident Peoples and Swaziland's Malolotja National Park: A Success Story', in Patrick C. West and Steven R. Brechin (eds.) Resident Peoples and National Parks. Tucson: The University of Arizona Press. pp. 61-67.

Obunde, Paul O. et al. (2005): 'Policy Dimensions in Human-wildlife Conflicts in Kenya: Evidence from Laikipia and Nyandarua Districts', Institute of Policy Analysis and Research of Nairobi, Discussion Paper no. 65. Available at: https://searchworks.standford.edu/view/6051009 (7 December 2018).

Pearson, Amber L. and Charles Muchunguzi (2011): 'Contextualizing Privatization and Conservation in the History of Resource Management in Southwestern Uganda: Ethnicity, Political Privilege, and Resource Access over Time', The International Journal of African Historical Studies 44(1): pp. 113140. Available at: https://www.jstor.org/stable/23046846 (7 December 2018).

Reynolds, Andrew (1995): 'The Case for Proportionality', Journal of Democracy 6(4): pp. 117-124. DOI: https://doi.org/10.1353/jod.1995.0071

Ross, Robert (2008): A Concise History of South Africa. 2 ed. Cambridge: Cambridge University Press. DOI: https://doi.org/10.1017/CBO9780511805806 
South Africa (1976): National Parks Act, Act No. 57, 6 April 1976. Available at: https://www.sanparks.org/about/acts/NatParksAct.pdf (20 December 2018).

South Africa (2003): National Environmental Management: Protected Areas Act, Act No. 57, 18 February 2004. Available at: https://www.environment.gov.za/sites/default/files/legislations/nema amendment act57.pdf

(20 December 2018).

South African National Parks (2018): 'Annual Report 2017/2018.' Available at: https://www.sanparks.org/about/annual/ (8 December 2018).

South African National Parks (n.d.a): 'People \&amp; Conservation.' Available at: https://www.sanparks.org/conservation/people/about/history.php (10 December 2018).

South African National Parks. (n.d.b): 'Brief History.' Available at: https://www.sanparks.org/about/history.php (11 December 2018).

Stringer, Lindsay C. et al. (2009): 'Adaptations to Climate Change, Drought and Desertification: Local Insights to Enhance Policy in Southern Africa', Environmental Science \& Policy 12(7): pp. 748-765. DOI: https://doi.org/10.1016/j.envsci.2009.04.002

The Economist (2018): 'Democracy Index 2017: Free speech under attack.' Available at: http://www.eiu.com/Handlers/WhitepaperHandler.ashx?fi=Democracy Index 2017.pdf\&mode =wp\&campaignid=DemocracyIndex2017 (7 December 2018).

Thompson, Leonard (2014): A History of South Africa. $4^{\text {th }}$ edition. New Haven: Yale University Press.

Thondhlana, Gladman and Georgina Cundill (2017): 'Local People and Conservation Officials' Perceptions on Relationships and Conflict in South African Protected Areas', International Journal of Biodiversity Sciences, Ecosystem Services \& Management 13(1): pp. 204-215. DOI: https://doi.org/10.1080/21513732.2017.1315742

Tilly, Charles (1985): 'War Making and State Making as Organized Crime', in Peter B. Evans, Dietrich Rueschemeyer, and Theda Skocpol (eds.) Bringing the State Back In. Cambridge: Cambridge University Press. pp. 169-187. DOI: https://doi.org/10.1017/CBO9780511628283.008

van de Walle, Nicolas (2003): 'Presidentialism and Clientelism in Africa's Emerging Party Systems', Journal of Modern African Studies 41(2): pp. 297-321. DOI: https://doi.org/10.1017/S0022278X03004269

Wegner, Eva (2018): 'Local-Level Accountability in a Dominant Party System', Government and Opposition 53(1): pp. 51-75. DOI: https://doi.org/10.1017/gov.2016.1 